\title{
Techno, Frankenstein and copyright
}

\author{
MARK A. McCUTCHEON
}

Nordamerikastudienprogramm, Institut für Anglistik, Amerikanistik und Keltologie, Universität Bonn, Germany

E-mail: sonicfiction@gmail.com

\begin{abstract}
This essay argues that the widespread but not widely recognised adaptation of Frankenstein in contemporary dance music problematises the 'technological' constitution of modern copyright law as an instrument wielded by corporations to exert increasing control over cultural production. The argument first surveys recent accounts of intellectual property law's responses to sound recording technologies, then historicises the modern discourse of technology, which subtends such responses, as a fetish of industrial capitalism conditioned by Frankenstein. The increasing ubiquity of cinematic Frankenstein adaptations in the latter two decades of the twentieth century outlines the popular cultural milieu in which Detroit techno developed its futuristic aesthetic, and which provided subsequent dance music producers with samples that contributed to techno's popularisation. These cultural and economic contexts intersect in an exemplary case study: the copyright infringement dispute in 1999 and 2000 between Detroit's Underground Resistance (UR) techno label and the transnational majors Sony and BMG.
\end{abstract}

\section{Introduction}

When London, Ontario's DJ Capital J (a.k.a. Jason Bunsie) began performing regularly at Toronto parties in the late 1990s, his sets included a self-produced dub plate that became a floor-filling anthem for Toronto's junglist massive. The plate grafts the triumphal first bar of John Williams' Star Wars theme to a jump-up bass hook and a self-promotional vocal loop: 'Right right set now / My my my my my man / On on on the decks - Capital J!' (Capital J [n.d.], Untitled). The track extends hardcore techno's tradition of sampling as a cheaper alternative to instrumental performance, a tradition whose roots Simon Reynolds identifies in 'early hip hop', for which 'sampling was like Frankenstein's monster, funk-limbs crudely bolted together' (Reynolds 1998, p. 45). The resulting bombast of J's track echoes that of proto-jungle hardcore acts like The Prodigy, whose 1992 single 'Out of Space' popularised hardcore's ready-made sampling tradition by splicing Max Romeo's 'Chase the Devil' with the Ultramagnetic MCs' 'Critical Beatdown'.

Capital J's track appropriates three notable referential functions of the sample for his own performance practice. Firstly, this sample cites a colonial war story that pits rebels against an evil empire: is this a message to the majors? In the films' soundtracks, the notes sampled by J often herald combat scenes where the rebels start kicking imperial ass. Thematising military conflict, the sample thus engages the rhetoric of rivalry and 'clashes' that jungle derives, like hip hop, from 'sound' 
culture (Gilroy 1987, p. 166). Secondly, Capital J's unlicensed use of the sample exemplifies the critique of corporate copyright theorised by Porcello (1991) and Schumacher (1995), and thus re-territorialises one theme of his source text. For Star Wars is an unsettling family romance, motivated by ambitious presumption (the title of the first stage Frankenstein [Levine and Knoepflmacher 1979, p. xx]), and grounded in technologies of clones, cyborgs, and planet-destroying weaponry. ${ }^{2}$ So, like most other Hollywood science fiction today, Star Wars adapts the story of Mary Shelley's Frankenstein. Thus, Capital J's unlicensed sampling of Williams' score represents a secondary adaptation, through successive regimens of recording technology: studio production, improvised turntablist performance, mix tape distribution, and online upload. Lastly, Capital J's adoption of the Star Wars theme to announce his performance echoes the similar use of the same track by Detroit radio DJ Electrifyin' Mojo (a.k.a. Charles Johnson) in opening the 'Midnight Funk Association' show that influenced the innovators of Detroit techno (Eshun 1998, p. 101). Capital J's performance thus plays out the mechanisation of music-making labour 'as an alien power' (Baldick 1987, p. 132) that subverts the copyright protection of sound recordings while re-inscribing the 'author function' (Foucault 1984, p. 108) through DJ performance.

This anecdote encapsulates the present study's argument: that the widespread but not widely recognised adaptation of Frankenstein in contemporary dance music problematises the 'technological' constitution of modern copyright law as an instrument wielded by corporations to exert increasing control over cultural production. In making this argument I draw on Mark Slobin's theoretical distinctions among sub-, inter-, and super-cultural production (Slobin 1996, pp. 100-1): 'Super- suggests an overarching category, sub- an embedded unit, and inter- a crosscutting trend' (ibid., p. 12). Slobin's deliberately sketchy use of 'subculture' in theorising music production outlines it as a 'small-scale network' (ibid., p. 35); 'supercultural' production refers to the nexus of industry and state (ibid., pp. 29-30) as embodied in Hollywood and major record labels that produce hegemony through financial, government, and media institutions; and 'intercultural' production can denote ethnic and diasporic articulations (e.g. Paul Gilroy's 'Black Atlantic' [1993]), or those between sub- and super-cultural practices.

This argument requires the elaboration of three related contexts. First, I survey some recent scholarly accounts of intellectual property law's responses to sound recording technologies, especially those of sampling and file-sharing. Then I historicise the modern discourse of technology, which subtends such responses, as a fetish of industrial capitalism shadowed by the 'modern myth' of Frankenstein (Baldick 1987, p. 1). The ascendant ubiquity of cinematic Frankenstein adaptations during an emerging post-industrial 'regime of flexible accumulation' (Latham 2002, p. 17) outlines the popular cultural milieu in which Detroit techno developed its particular variant of 'Black Atlantic Futurism' (Eshun 1998, p. -005), and which provided subsequent dance music producers with samples that contributed to techno's popularisation.

These contexts intersect in the exemplary case study of a copyright infringement dispute in 1999 and 2000, between Detroit's Underground Resistance (UR) techno label and the transnational majors Sony and BMG. According to UR, Sony pressed and began distributing an unlicensed cover of the Detroit label's popular 'Jaguar' track. That Sony and BMG merged in late 2004, leaving some eighty per cent of the global music market under the management of four companies ('Indies challenge' 2004), underscores the issues discussed here. 


\section{The propriety of art in the age of mechanical reproduction}

The transnational oligopoly of these four companies owes its privilege in part to the responses of intellectual property laws to sound recording innovations in the early twentieth century. As David Laing writes, the dominance of the record industry over popular music production in the latter twentieth century depends on the 'ownership of copyright in sound recordings by record companies rather than by musicians':

That grant of ownership was one of two important innovations created in the United States copyright legislation of 1909. This law was drawn up, in part, to take account of new technologies that had changed the configuration of cultural production in the previous one or two decades. Probably the most important of these were the cinematograph and the various means of mechanical reproduction of musical works, notably the phonograph [. . .] the resulting legislation provided the early record labels with a legal status comparable to that of the (then) all-powerful music publishers. (Laing 2002, pp. 185-6)

Laing notes this legislation's crucial attribution of authorship to corporations, not musicians (ibid., p. 185), and the irony that legislation introduced to curb the music publishers' 'dangerous monopoly' has virtually instituted one for the record industry (ibid., p. 186). He then contrasts the industry-dominated patenting and marketing of successive 'recording technologies and consumer electronics products' (e.g. digital audiotape, CD) with 'a new kind of distributor' represented by online file-sharing (ibid., p. 193), noting the record companies' 'hostil[ity] to this first generation of music hardware technology not controlled by the music industry' (ibid., p. 192).

Like Laing, Steve Jones (2002) and Peter Grant and Chris Wood (2004) suggest that the record industry is poised to reassert its dominance in the online domain, through its formidable advantages in marketing, capital, and law. These critics, among others, analyse modern copyright property law as an instrument for arrogating the control of cultural production to major corporations, amidst the globalising markets of 'blockbusters and trade wars' (Grant and Wood 2004, pp. 3-4). Grant and Wood's discussion of the 'curious economics' of popular culture identifies copyright law as a monopolising tool in itself (ibid., p. 49), enabling, for a given work, arbitrary 'price discrimination between markets' (ibid., p. 54):

copyright law [.. .] maximises that effect [i.e. price discrimination] by abetting the subdivision of markets into temporal windows and territories of exploitation. The game then is to play out a property across as many windows and territories as possible, extracting maximum return from each. (ibid., p. 85)

To explain why only 'big' players - i.e. transnational, diversified corporations usually succeed, they add that 'to do this, it is helpful if you happen to own or control a significant number of windows or territories' (ibid., p. 85). Territories must be understood here not only as geographically distinct markets, but also as distinct consumer media 'formats'; Laing notes that Sony's patent on compact-disc technology combines with its music division copyright properties to consolidate its 'vertical integration' (ibid., p. 193).

The rhetoric of 'revolution' that marks so much marketing of consumer technology can be attributed in part to Marshall McLuhan's theory of the Gutenberg revolution, in which the early modern advent of printing technology transformed the medieval ontology mediated by manuscripts. As David McKitterick suggests, the figure of revolution, in which new media compete with old, may be less historically accurate than that of mutual accommodation and benefit (quoted in Saunders 2005, p. F3). However, the more arresting figure of revolution dominates the bourgeois 
social imaginary, driven in part by modernity's distinctive ambivalence toward technological innovation. This ambivalence - which inflects the modern usage of 'technology' itself, through the popular mediations of Shelley's Frankenstein - marks the reception and representation of successive and competing sound recording technologies of both production (e.g. samplers) and consumption (e.g. file sharing).

Thomas Porcello's study of sampling ethics dramatises the anxieties over labour redundancy and musical authenticity with which many audio engineers viewed digital sampler technology in the 1980s. His interview subjects, professional audio engineers, frequently figure sampling as 'dehumanising': When one interviewee 'speaks of how samplers "dehumanise" music, he is commenting not only on effective qualities in the musical product, but [also ....] the production process itself in which machines are physically replacing humans' (Porcello 1991, p. 82). Porcello repeatedly cites one interviewee's comparison of out-of-work musicians to laid-off Detroit auto workers (ibid., pp. 76, 78, 82) to illustrate music industry perceptions of 'interchangeable' technicians (ibid., p. 80) and musicians as wage labourers (ibid., p. 81).

Thomas Schumacher expands on Porcello's closing reference to 'oppositional' sampler use in hip hop (ibid., p. 82) to theorise how sampling enables dialogic possibilities for cultural production that counter music industry hegemony. Quoting Bettig's (1992) comment that 'intellectual property rights continue to be utilised to gain or maintain market advantages by an increasingly oligopolistic and multinational culture industry', Schumacher supports it by observing that court decisions in audio sampling cases consistently favour the copyright owners, 'securing the rights of the corporate legal subject over the concerns of cultural expression' (Schumacher 1995, p. 266).

Jones (2002) describes the problems posed for the corporate exploitation of copyright by new media's short-circuits of distribution through an image of uncontrolled technology similar to Laing's: 'The industry [...] is in the process of using legal means with which to establish new loci of exchange for the movement of digital goods in which it owns rights' (ibid., p. 223). Until or unless 'the industry' establishes such loci, Jones speculates, its 'ability to control a "mainstream" of music [. . .] will, at least in the short term, be severely tested, as music moves across digital networks with, at best, licensing providing the only revenue source to copyright holders' (ibid., pp. 223-4).

The music industry's campaign against file-sharing reproduces earlier historical campaigns against not only samplers but also against phonographs and juke boxes, which, as Sarah Thornton documents, were constructed as a similar threat to live (read: authentic) musicianship (Thornton 1996, p. 34). In this long tradition, the major labels' current copyright campaign aligns itself with labour interests by appealing to authorial originality as a principle of 'making one's living', in opposition to a technology figured as theft, as the privation of 'honest' labour.

Lee Marshall suggests that corporate recourse to legal and legislative means, like blank media taxes and extensions of copyright protection periods, demonstrate copyright law's 'economically irrational' dependence on a Romantic ideology of authorship that mystifies the major labels' ruthless pursuit of profit (Marshall 2002, p. 6). Schumacher describes this 'irrational' rationalisation as 'one of the fundamental contradictions in legal theory: its reliance on the myth of the original, individual author coupled with the abandonment of the author-subject for the corporate rights-holding-subject' (Schumacher 1995, p. 270). 
Laing echoes Marshall's reference to a Romantic ideology of authorship: 'the residual aura of authorship guarantees that this will be more highly rewarded than the "industrial" connotations of recording' (Laing 2002, p. 182). Laing's summary of copyright law's stake in 'utility' (ibid., p. 179) evokes the Utilitarian philosophy of Jeremy Bentham, criticism of whom often referred to Frankenstein (see Morton 2002, pp. 85-8).

\section{Frankenstein and the fetish of industry}

Current intellectual property law in music production thus represents an 'order of discourse' (Foucault 1981, p. 48) limiting the proliferation of cultural reproduction technologies. In the above-quoted critiques, 'technology' and 'control' become crucially paired signifiers whose conjunction suggests how anxiety over technology is integral to the modern meaning of the word. The centrality of technologically motivated anxiety to copyright law itself depends on the fetish image that the term technology has come to evoke, an image shaped early in the nineteenth century by corresponding transformations in the meaning of 'industry', as traced by Raymond Williams:

in the last decades of the eighteenth century, industry [. . . ] became a collective word for our manufacturing and productive institutions [. . .] Industry, with a capital letter, is thought of as a thing in itself - an institution, a body of activities - rather than simply a human attribute. (Williams 1958, p. 13)

Williams' account of Industry's reification as a 'thing in itself' contextualises the related transformation in the term 'technology' during the Industrial Revolution. During the Victorian period, technology traded in its earlier meanings as both the 'study of an art or arts' and 'the terminology of a particular art or subject' to assume its modern meaning as a collective noun for the 'practical' or 'industrial' arts, their processes and products $(O E D)$. While the $O E D^{\prime}$ 's first citation of the modern meaning of 'technology' dates from 1859, David Nye (1994) notes that this modern meaning was innovated by Harvard medical professor Jacob Bigelow in 1828, whose Elements of Technology made the now familiar claim that ' $\mathrm{t}$ ] he labour of a hundred artificers is now performed by the operations of a single machine' (quoted in Nye 1994, p. 45). Nye suggests that 'only gradually did "technology" acquire the all-encompassing sense it commonly has today. In the middle of the nineteenth century, technical universities began to call themselves institutes of technology, and the word began to take on the connotation of utilitarianism (as distinct from "science")' (ibid.).

But as Baldick argues, 'technology', as increasingly popular metonymy for machinery, also began to assume monstrous connotations during the Victorian period. 'What I shall call the technological reduction sees the story [of Frankenstein] chiefly as an uncanny prophecy of dangerous scientific inventions' (Baldick 1987, p. 7). Baldick describes the fetishistic connection between Frankenstein and technology thus: 'The technological interpretation of the myth resembles many influential diagnoses of "the machine age" in that its isolation of the machine as the root evil of modern civilisation merely reinforces the very fetishism of mechanical power which it sets out to deplore' (ibid., p. 8).

One of the most "influential diagnoses of "the machine age" to which Baldick refers is Thomas Carlyle's 1829 essay 'Signs of the times', which criticised Utilitarianism, identifying it with 'mechanism' as opposed to organic, human 
'dynamism'. Describing his era as 'a time of unmixed evil' (Carlyle 1829, I16), as 'the Age of Machinery' (ibid., I19), Carlyle reserves his harshest condemnation of 'the Genius of Mechanism' (ibid., I12) for its permeation of the cultural and religious domains of human life, a permeation achieved through various technologies of reproduction, specialisation and incorporation. 'Literature, too, has its Paternoster-row mechanism, its Trade-dinners, its editorial conclaves, and huge subterranean, puffing bellows; so that books are not only printed, but, in a great measure, written and sold, by machinery' (ibid., I112). Carlyle's equally vivid characterisation of this technological literature's content as 'not a matin or vesper hymn to the Spirit of Beauty, but a fierce clashing of cymbals, and shouting of multitudes' (ibid., I136) anticipates the Futurist 'art of noise' that several commentators have canonised as techno's avant-garde heritage (see Shapiro 2000, pp. 4-7).

Carlyle's anxiety over the mechanisation of literature centres on changes in its modes of reproduction, and thus prefigures the arguments against technological change made by music industry representatives since the early twentieth century. Similarly, his image of mechanised literature anticipates later receptions of dance musics from jazz to disco that devalue them as synthetic, mechanical and inauthentic, receptions critiqued by Tricia Rose (1995, p. 103), Susan McClary (1994, pp. 31-2), and Walter Hughes (1994, p. 151). Adorno's image of 'jitterbugs', whose 'ecstasy [. . .] has convulsive aspects reminiscent of St Vitus's dance or the reflexes of mutilated animals' (Adorno 1991, p. 46), precisely echoes Carlyle's 'galvanic' images of 'modern humanity as a disconnected and fragmented automaton' (Baldick 1987, p. 103): 'For Carlyle galvanism is the appropriate image for the modern state of possession, in which tremendous energies work themselves out only as undirected physical reflexes. His galvanic world is a world of the living dead' (ibid., p. 106). 'Mechanism' itself becomes Adorno's figure for the popular music industry of which the jazz fan is a particularly 'regressive' symptom (Adorno 1991, pp. 46-8). However, in direct opposition to Adorno and his elitist influence on popular music criticism, arguments by Hughes, Rose, Kodwo Eshun, and Ben Williams (2001) suggest that the 'technological reduction' of dance music produces empowering forms of 'technological identification' (Hughes 1994, p. 151): 'Becoming robots was, for African American musicians, a subliminally political act [. . .] a form of self-empowerment' (Williams 2001, p. 161). Hughes figures this identification for queer disco scenes in clearly Frankensteinian fashion: 'The fearful paradox of the technological age, that machines created as artificial slaves will somehow enslave and even mechanise human beings, is ritually enacted at the discotheque' (Hughes 1994, pp. 151-2).

As Nye notes, 'ambivalence toward technology was more prevalent in England than in the United States. [. . .] The English were prone to view industrialisation in terms of satanic mills, frankensteinian monsters, and class strife', whereas he characterises the American attitude to technology as more receptive, inflected with positive moral connotations (Nye 1994, p. 54). Early English responses to mechanical production modes organised the modern distinction between culture and nature in industrial terms, pitting 'mechanism' against 'dynamism', or technology against humanity, as dramatised by Shelley's 'modern Prometheus'. Complicating Nye's national distinctions, Baldick finds Frankenstein references in US writers like Nathaniel Hawthorne and Margaret Fuller (Baldick 1987, pp. 70-3) as readily as in British figures; and the 'technological reduction' of Frankenstein that begins avant la lettre with writers like these continues with Marx himself (ibid., p. 132) and Victorian sensations like Bram Stoker's Dracula, whose technologies of cultural reproduction Mark Seltzer traces to 
theorise the modern 'body-machine complex' (Seltzer 1993, p. 102). Seltzer sketches the contradictory problematic of technology in current criticism as both 'an emptying out of human agency' and its 'extension': the 'double logic of technology as prosthesis' (ibid., p. 99). The abundance of trans-Atlantic adaptations of Shelley's 'modern myth' has marked the current meaning of 'technology': as fetish, as reified labour, as the machine in the ghost.

\section{The filmic annihilation of the labour force known as man}

As Baldick argues, the 'modern myth' of Frankenstein consists of the myriad 'adaptations, allusions, accretions, analogues, parodies, and plain misreadings which follow upon Mary Shelley's novel' (Baldick 1987, p. 4). The proliferation of Frankenstein film adaptations during the period in which Reagan and Thatcher began to implement the labour-disorganising economic policies of post-industrial globalisation represents a super-cultural symptom of this regime, and an important context for historicising Detroit techno. The particular super-cultural texts discussed here should be familiar to most readers (in brand power, if not in detail). As popular cultural products, these texts fare poorly in the judgement of both academic science fiction specialists (see Aldiss 1986, p. 73) and more canonically minded scholars. But it is precisely the popularity of these 'mainstream' products that makes them available to 'underground' appropriations, and establishes their use for cultural studies.

Timothy Morton's Literary Sourcebook on Mary Shelley's Frankenstein (Morton 2002) lists among its film adaptations (pp. 74-8) many of these widely sampled movies: Blade Runner (1982), Videodrome (1983), The Terminator (1984), Robocop (1987), Star Trek: The Next Generation (1987), and The Matrix (1999). Morton's inclusions are authoritative, and I refer the reader to them rather than explicate them here. But Morton's film omissions are considerable, and his musical omissions (ibid., p. 79) even more so, given the adaptation practices mapped here; Blade Runner and Terminator samples in particular abound in dance tracks (e.g. Love Child's 'Time travellers', Andora's 'Blade Runner', and 'Terminator II' by Rufige Cru [a.k.a. Goldie]). Morton applies a more selective or literal theory of adaptation than Baldick's outline of Frankenstein's myth-generating 'skeleton story' - its premise of artificial intelligence and its plot of a creator threatened with destruction by its creature (Baldick 1987, p. 3) - an outline that establishes criteria for counting as Frankenstein adaptations not only Star Wars (1977), but also Battlestar Galactica (1978) and Max Headroom (1987).

As mentioned above, Star Wars grounds its plot of anti-imperial insurrection in the power-structuring technologies of cyborgs, cloning, and planet-destroying weaponry. Moreover, Darth Vader's effective transformation of his son Luke Skywalker into a cyborg like himself reflects the doubling of Shelley's characters. Among the dance tracks sampling Star Wars are the aforementioned Capital J track, Underground Resistance's Death Star EP, and Sir Round's 'Imperial march'.

Battlestar Galactica (1978) bases its plot more obviously on Frankenstein, as an army of cyborg human clones called 'Cylons', bent on 'the final annihilation of the life form known as man', pursues a 'rag-tag fugitive fleet' of the galaxy's remaining humans. ${ }^{3}$ With special resonance for this study, the charges of copyright infringement that Lucas' empire brought against Larson's Battlestar (Aldiss 1986, pp. 273-4) prefigure the controversy in which Underground Resistance (UR) became embroiled with Sony (although a dispute between two major players differs significantly from one between a major and a minor). Battlestar found contemporary dance adaptation with 
Italian disco producer Giorgio Moroder, an acknowledged influence on the early Detroit scene (Sicko 1999, p. 45), who released Music from 'Battlestar Galactica' and other original compositions. Subsequent dance adaptations have been issued by Kenny 'Dope' Gonzalez, Acen, and the Cylon drum and bass label.

Moroder's album covered the disco song 'It's love, love, love', which provided the soundtrack to a nightclub scene in the Battlestar pilot, according to the nowformulaic mise-en-scène whereby science fiction films adopt the subcultural sounds of the present to conjure a futuristic world. Similarly, techno and New Wave soundtracked Max Headroom, a self-reflexive experiment in cyberpunk television, whose talking-head protagonist delivers McLuhanesque satire to the haves and have-nots of a post-apocalyptic metropolis under transnational corporate rule. The local media's inability to control its 'star reporter's' artificially intelligent alter ego, and the sinister yet booming business of the Body Banks are two of the overtly Frankensteinian aspects of this franchise, which also leased its title character to the sampler-based band Art of Noise for the 1986 single 'Paranoimia'.

\section{Afro-futurism in Dr. Funkenstein's 'Techno City'}

In this milieu, techno 'was recognisably related to the presiding utopian - and dystopian - prophecies of its time: Alvin Toffler's book The Third Wave (published in 1980), Ridley Scott's movie Blade Runner (released in 1982), William Gibson's novel Neuromancer (published in 1984)' (Williams 2001, pp. 154-5). Like Dan Sicko's popular history, Techno Rebels (1999), Ben Williams contextualises the origins of Detroit techno and the work of later producers like UR according to the new global space of postindustrial capitalism' (ibid., p. 155). And like Ken McLeod in a recent issue of this journal (McLeod 2003), Williams locates Detroit techno in the 'Afro-futurist' tradition theorised by Eshun (1998), Mark Dery (1993), John Corbett (1994), Julian Jonker (2002), and Erik Davis (2004).

The omission of Williams' work from McLeod's survey of space and alien tropes in popular music (McLeod 2003) represents only one problem with the latter article. More serious are signs of McLeod's unfamiliarity with the scenes he surveys: he misspells the names of Cybotron's collaborators (ibid., p. 344); he rehearses common, celebratory clichés about 'rave'; and he simply misreads 'ragga' in claiming that the 'polyrhythmic drum and bass lines' of jungle are 'influenced by Indian ragas' (ibid., p. 344). For our purposes, McLeod's deferral of the capitalist problematic represents this article's main methodological problem. Eschewing the Marxist theory of alienation in favour of a use of the term 'alienation' in its more existential sense, McLeod makes the sweeping claim that 'rock's fascination with science fiction themes [...] is dependent upon a sense of God's withdrawal from the universe and upon a radical sense of alienation from the traditional belief structures that have governed life on earth' (ibid., p. 349). His definition of 'the postmodern condition' cites Jameson in passing, omitting reference to the late capitalist structures that produce postmodernity's 'loss of subjectivity' (ibid., p. 352). While McLeod's discussions of rave and Afro-futurism do not entirely omit reference to capitalism, neither do they yield the insight afforded by more sustained attention to the labour contexts of industrial and post-industrial capitalism that enable sound system culture's articulations of 'technological rationality' (Gilroy 1987, p. 180).

Some of the questions that McLeod raises by mapping music's space and alien images become clearer by focusing on Frankenstein in particular. For instance, John 
Corbett's analysis of the 'space madness' of Lee Perry, Sun Ra, and George Clinton, which McLeod cites, suggests how each of these artists adopts the Frankensteinderived personae of both creator and creature to problematise his diasporic identity and his relation to the music industry (Corbett 1994, pp. 21-2). 'In each case, the boundary between human and machine is blurred, and myths, electronics, defense weapons, and musical instruments conspire with people to produce the fuzzy image of the cyborg' (ibid., p. 19). ${ }^{4}$

Corbett's critical triumvirate of Ra, Perry and Clinton informs McLeod's and several other accounts of Afro-futurism, like those by Davis, Eshun, and Jonker, canonising touchstones for techno's futurism in earlier black Atlantic musics. Williams points to Detroit native Clinton's 'fusion of high-tech rhythm and space age fantasy' as an 'immediate regional influence' on techno's originators (Williams 2001, p. 162). Julian Jonker's discussion of Afro-futurist artists clarifies their 'scientific' disciplines of knowledge that complement the racialised 'madness' theorised by Corbett. Stressing the role of formal experiments in diasporic Afro-futurism (Jonker 2002, I131), Jonker notes that science fiction 'reflects the American racial psyche' with 'themes like alienation, colonisation and technology as a disciplinary epistemology', and argues that Afro-futurist music occupies a critical 'interface of science and aesthetics' (ibid., I19) in which 'black secret technology is taking white technology apart and not putting it back together properly' (ibid., II32). The resulting "'versions" of dub technology' (e.g. reggae, hip hop, techno, etc.) represent the black Atlantic's uprouted 'double consciousness' (ibid., II44).

Gilroy's theory of sound system culture's anti-capitalist critique (Gilroy 1987) anticipates Jonker's argument. Jonker quotes Gil Scott Heron on the absurdity of government space programmes in light of racialised economic disparity (Jonker 2002, II), echoing Gilroy's treatment of the 'space flight' trope in mid-1970s black dance music (Gilroy 1987, pp. 201-2). For Gilroy, the 'interplanetary themes in the soul and funk of this period provided a means to satirise American imperialism and to advance utopian visions of a reconstructed society' (ibid., p. 180). Gilroy grounds his theory of black dance music's anti-capitalism in its scenes of performance - the sound systems themselves - as 'public' scenes of 'dialogic' music-making: 'dances, clubs, parties and discos' (ibid., p. 211) construct community while critiquing both the temporal order of labour and the commodity form itself (ibid., p. 210). But Gilroy's attribution of counter-cultural agency to black Atlantic music appears to extend only as far as hip hop. Gilroy's recent arguments $(1999,2000)$ against the 'deskilling, dehumanising technologies' (Gilroy 1999, p. 267) that produce dance beats as 'workout music' (ibid., p. 269) identify in this music a symptom of the decay of the black public sphere. Gilroy's techno-fetishising image of dance music's culture industry explicitly echoes Adorno:

The mechanisation and the militarisation of rhythm are being practised under the sign of generic dance music. House and its proliferating 'technocratic' offshoots culminate in a kind of imprisonment of rhythm. Rhythm is under house arrest. Frail, feeble, and funky humanity has been expelled and the sinuous warmth of real-time bass and drums is largely surplus to its requirements. Surprisingly, the phrase 'the regression of listening' springs to mind to make some sense of this, for ears are no longer tuned in to the possibility of distinguishing the sampled from the played. (ibid., pp. 269-70)

Numerous problems invite a response: for one, the homogenising caricature of dance music's receptions; for another, the inattention to how aura persists in dance beats, from production, where live improvisation generates samples as often as 
computer-programmed breaks do, to reception, where DJ performances can affirm the 'liveness' of their performance as easily as surrender it. The dispute between UR and Sony over the unlicensed re-recording of an exclusively synth- and samplerproduced record instantiates one form of aura's persistence in scenes structured by mechanical reproduction. In 'expelling' humanity, Gilroy's 'technocratic' image of dance beats rehearses a Frankensteinian trope of mechanical over-determination that dismisses the human labour that produces and consumes these musics. Evoking Adorno's denigration of jazz, Gilroy's 'generic' characterisation of dance music misrecognises the textured hybridity that historically constitutes it and reinforces the traditional disrespect that music critics reserve for dance genres (as analysed by McClary 1991, p. 153; Gilbert and Pearson, p. 61).

But as Eshun argues, the Futuristic and surrealistic abandonment of humanist paradigms and essentialist constructions of black identity - those against which Gilroy argues - is precisely the point of 'sonic fictions' (Eshun 1998, p. -003). Eshun's reading of techno's 'underground' ethos drives this point home:

Techno secedes from the street, the street which is widely assumed to be the engine of black popculture [. . .] In vanishing from the street, and from Trad HipHop's compulsory logic of representation and the will to realness, UR [Underground Resistance] identifies not with the low end but the high end of technology. [ . . .] UR [ . . .] moves into the Military Industrial Complex because the MIC precedes and predetermines the street. (ibid., p. 117)

Techno's problematic relation to 'the street' is a Motor City poetics that both fetishises and resists the music's mechanical reputation, a reputation mirroring that of Detroit, where black suburbanites Juan Atkins, Kevin Saunderson and Derrick May pioneered the sound in the early 1980s. May's famous homology compared the dance sound to the city itself as 'a complete mistake. It's like George Clinton and Kraftwerk stuck in an elevator' (quoted in Sicko 1999, p. 26). This juxtaposition loses its ostensible surprise in light of how both Clinton and Kraftwerk funked up Frankenstein: the former, as Dr. Funkenstein; the latter, as robotic synthesizer champions (Reynolds 2000, p. 33).

Juan Atkins collaborated with Rik Davis to form the production duo Cybotron, which referred to Alvin Toffler's Third Wave in tracks like 'Techno City'; references like these earned the Detroit circle an enduring reputation as exemplars of Toffler's 'techno rebels'. Atkins has discussed his music in the Fordist terms adopted earlier by Motown producer Berry Gordy: "'I'm probably more interested in Ford's robots than Berry Gordy's music" [.. .] Atkins instinctively homed in on the robots that replaced humans on the conveyer belts and connected them to the decline of the industrial model, both economically and musically' (Williams 2001, p. 161). Creatively abusing 'trailing-edge' equipment, techno's originators produced futuristic-sounding tracks with 'lyrics like "don't let them robotise your mind" ... [that] testify to an ambivalent investment in technology' (Reynolds 1998, pp. 19-20). What better place than Detroit to foster such 'ambivalent investment'? The 'critique of productivism' (Gilroy 1987, p. 199) in black Atlantic dance music means, for Detroit's 'techno rebels', a critique of the shift from Fordism to post-industrialism that made Detroit an early, emblematic casualty of globalisation (Sicko 1999, pp. 59-60).

Although the word 'techno' circulated among producers and their tracks (Atkins quoted in McCall 2001, p. 30), the term was not used to market a genre until British record executive Neil Rushton approached the Detroit circle to release the compilation album Techno! The New Dance Sound of Detroit with Virgin Records in 1988 (Sicko 1999, p. 99). The diasporic subjectivities and intercultural money flows that nurtured the development of techno have thus condensed in the genre's name a 
legacy of the multiple 'futurisms' of modernity (Campbell 2003): the 'futuristic' temporality of science fiction; the Futurist avant-gardes of the early twentieth century; and 'futurist' punditry like that of Toffler and McLuhan before him. The genre's name also engages the Utilitarian legacy, not only in its abbreviation of one of that legacy's organising figures, but in how the abbreviation as such parodies the efficiency- and profit-motivated cutbacks that produced Detroit's post-industrial 'ruins'. 'Techno', or means, without 'logy', or motive, further expresses the Detroit circle's ambivalence towards technology, suggesting that another world is possible while furnishing a driving, regimented soundtrack for 'the aggressive liberalisation of recent decades' (Stokes 2000, p. 219).

Like the 'the irreducible element of mediation in its sound', techno's abrogation of authenticity and its tension between dystopian techno-Luddism and Utopian techno-fetishism may explain the music's unpopularity in the US (Williams 2001, p. 163), where the sound's wary ambivalence, while 'a product of our environment' (Pullen quoted in Williams 2001, p. 161), ironically alienates a domestic audience accustomed to associating technology with progress and manifest destiny, as Nye suggests. But these elements may likewise explain techno's intercultural success in Europe.

While Toffler, Dr. Funkenstein, Blade Runner and Neuromancer suggest postindustrial intertexts for techno's emergence, a telling distinction between the first domestic and subsequent international 'waves' of techno's development lies in their sampling practices. Early Detroit techno used samplers to generate abstract sounds and defamiliarise vocals, but conjured its 'iconography of the future' (Gilbert and Pearson 1999, p. 75) with hardly any explicit samples of supercultural texts. In contrast, one effect of precisely such explicit sampling by later (especially British) techno producers has been to popularise the music. The 1988 hit 'Doctorin' the Tardis' by the Timelords (a.k.a. Jimmy Cauty and Bill Drummond, a.k.a. the KLF) sampled the Daleks, robotic 'superior beings' from 'Doctor Who'. Goldie's 'Terminator II', a seminal prototype for drum and bass, sampled dialogue from the eponymous film. The crossover techno act Messiah (a.k.a. Ali Ghani and Mark Davies) opened its 1994 album, 21st Century Jesus, with an apocalyptic announcement of the age of the machine' and littered its tracks with Hollywood science fiction samples that amplify the bombast of their relentless, abrasive breakbeats. Madame Zu (a.k.a. Julia Winters) was among the first of countless producers to sample The Matrix, with 'Matrix 999 (The Red Pill)', which splices dancefloor exhortations with film dialogue: 'Let let let let let let let let let let let the bass kick / All I'm offering is the truth'.

\section{'Wreak havoc on the programmers'}

On the domestic front, the production practices of Underground Resistance, one of the Detroit labels that 'picked up where May, Atkins, and Saunderson left off in the early 1990s' (Williams 2001, p. 164), have also adapted Frankenstein, and not simply by activating their own slogan to 'wreak havoc on the programmers' through the media campaign against Sony in retribution for the purloined 'Jaguar' track. The label's co-founder, 'Mad' Mike Banks, has said: 'I think Terminator is definitely what's happening man - machines have emotions. They can become intelligent and they will one day' (quoted in ibid., p. 167). Banks formerly 'played bass in one of Clinton's many spin-off bands, the Brides of Funkenstein' (ibid., p. 164), and he expresses a visceral sense of alienation in reflecting on his mixed heritage: 'I'm not a friendly native no 
more. I've been modified into some different shit' (quoted in Wraight and Nodu 1996, p. 26). The title of UR's 1998 Interstellar Fugitives album evokes the 'fugitive fleet' of humanity's survivors in Battlestar Galactica, while its tracks, with titles like 'Maroon' and lyrics that theorise 'a fundamental technological alteration in [...] what it means to be human' (Williams 2001, p. 169), evoke the displacement and subjugation that define black American history.

Eshun also illuminates some of UR's other Frankenstein adaptations: Robert Hood as 'The Vision' (Marvel Comics' 'anguished android' [p. 118]); the Death Star EP; and UR's 'monstrous' mantra: 'Wreak havoc on the programmers!' (quoted in Eshun 1998 , p. 122). Furthermore, he traces a line of influence from the identifications of Clinton, Perry, and Ra with both creature and creator to the similar identifications of techno producers with both the manufactured robot figure and the manufacturing sound engineer: 'in the films Predator 2, Ghost in the Shell, the Alien tetralogy, it's always the engineers who are ready to turn the alien into killer app' (ibid., p. 111). ${ }^{5}$ Likewise, Williams claims that UR's combination of 'localised self-sufficiency' and mysticism 'would result in a new form of racial subjectivity' (ibid., p. 164): 'the body that this music creates is [. . .] redefined by [cyborg] technology' (ibid., p. 167).

After Atkins, May, and Saunderson became internationally famous as touring DJs (Reynolds 1998, p. 219), UR became a leading exemplar of techno's domestic 'second wave' of younger producers who inherited the local scene. In its productions and business practices, UR amplifies techno's Futurist militarism, while inscribing its authenticity through the 'hard city' imagery of post-industrial Detroit.

'For several months before they released anything, Jeff Mills and Mike Banks (a.k.a. Mad Mike) planned and theorised their operation' (ibid., p. 219). The trenchant independence for which UR became, according to one fan, 'the most revered techno imprint in the world' ('Label profile') materialises in the label's records and in its networked (if not exactly vertical) business integrations, to maintain critical distance from a mainstream music industry that UR describes as 'the programmers'. UR's signal innovation in vinyl form is the 'locked' groove, circular instead of spiral, developed by veteran Detroit record-cutter Ron Murphy in collaboration with Mills on UR's 'Rings of Saturn' EP (Sicko 1999, p. 158); the improvised use of locked grooves by techno DJs has since become a sign of virtuosity. In its business model, UR restricts use of its 'Black Planet' studio to its own signed artists, 'ke[eps] interviews to a minimum and let[s] its products do the talking' (ibid., p. 145), preferring online and fax communiqués to mass media exposure ('About Underground Resistance'), and retains firm control over its creative direction. Determined to control as many means of production as possible, Banks teamed up with Christa Weatherspoon Robinson in 1992 to establish Submerge to centralise administration for local dance music labels. Submerge manufactures the recordings and merchandise for UR and some dozen affiliated labels, and distributes these products as wholesaler and retailer, in addition to promoting and publishing its labels' products. While Submerge's publishing division handles licensing for UR and other Submerge labels, there appears to be disagreement over whether and how UR entertains product licensing by other labels and companies.

Sicko suggests some licensing activity on UR's part (ibid., p. 145), but its extent remains unclear, given Sicko's subsequent claim that 'the closest UR came to signing with any label was its agreement to contribute the song 'Elimination' to Mute's 1991 compilation Paroxysm' (ibid., p. 146). The popularity of 'Jaguar' and the Sony controversy have dated Sicko's claim for UR's licensing reservations. While 
Banks says that the label refused dozens of licensing requests before its conflict with Sony (quoted in DJ MG 2000, I5), the success of 'Jaguar' has since motivated UR to license this track to numerous clients, including the UK division of Detroit label 430 West ('430 West'; Askew) and several DJ mix CDs (e.g. Jon Carter's 7 Live \#1; MTV Extreme; Pete Tong's Essential Mix 2000).

Ten years after Derrick May's 'Strings of Life' defined techno for dancefloors across Europe (Reynolds 1998, p. 219), Rolando Rocha's 'Jaguar' refined that sound for dancefloors around the world. One Detroit Techno list member suggested that 'Jaguar's popularity derived from its formal similarities to 'Strings', particularly the elaborate synth-strings sequencing (Watkins). That performances of renowned DJs like Masters at Work, Ken Ishii, and Atkins have mixed these two tracks together in their playlists supports this formal connection (cf. A-Zed; Clark; Sokolowski). Released in March 1999, 'Jaguar' had become a club anthem - and UR's most popular release to date - by the year's end, when Sony Music's Frankfurt-based dance division began circulating a 'promo release' of a cover version of Rocha's track (Dreyer quoted in 'Sony Informs UR' 1999). The 'promotional' rhetoric in Sony A\&R manager Dirk Dreyer's communications with UR suggests limited circulation to record pools or specialty shops, and seems intended to reassure the label that Sony wasn't a competitive threat. We will return to the implications of 'promotional' expenditure for intellectual property law in cultural production after tracing the main points in the case.

\section{The case of the purloined 'Jaguar'}

While it is a testament to the enduring devotion of UR's 'underground' following that the subsequent account has been reconstructed through abundant documents archived online, we must note the methodological problems that arise in essaying anything like an authoritative account on the basis of such evidence. The archive mined here is compromised, mediated by numerous gatekeepers, and representative of the tension between representation and the real, fiction and history - the tension 'between perpetration and recollection' that Jacques Derrida calls 'the logic of the hymen . . . the consummation of differends' (Derrida 1981, p. 212). Simply put, the veracity of dates, names and events represented in the messages, journalism and commentary that comprise this archive remains unverifiable. That said, the online archive itself represents a durable effect of UR's campaign, and warrants our attention as such.

One striking fact in the case of UR versus Sony and BMG is the absence of a legal case. In an 8 December 1999 email, Banks reiterated UR's refusal to license the track, claimed Sony had not sought licensing permission, and outlined UR's strategy:

Unless Sony Music gives UR an open apology in all major press we will have no choice but to defend ourselves and not only ourselves but the whole of underground music! I intend on showing them that these wars will not be fought in the unfair conditions of their courtrooms where their corporate lawyers have an advantage! these wars will be fought in the new arena - out here in deep space where the playing field is more level. (quoted in DJ MG 2000, I66)

The compelling aspect of Banks' plan is his refusal to take the case to court, perceiving in the legal institution only service to corporate interests. In his coverage of the controversy, DJ MG speculates that Banks' rationale harbours a bottom-line anxiety: 'It is highly doubtful if a small record label like UR could survive a lawsuit against 
powerhouses like Sony and BMG [...] companies who have just filed a lawsuit against the Web site MP3.com for copyright infringement'. Despite later intimations that UR was considering pursuit of 'legal proceedings' (Harris 2000, 'Re: (313) Jaguar'), the label seems to have abandoned that pursuit. Not that UR didn't fight the law, as the song goes. Banks' refusal to close ranks on the officially recognised field of legal battle constitutes a different kind of fighting the law: a challenge to its legitimacy, a critical recognition of 'the law of the law' (Derrida 1992, p. 191), of its history as an institution to enforce ruling-class security. UR's tactic also implies the recognition of copyright law's 'abandonment of the author-subject for the corporate rights-holder' (Schumacher 1995, p. 270 n. 11) - albeit paradoxically, given UR's own corporate status.

Sony's 'promo release' of its 'Jaguar' cover version reached the US market in December 1999 (PW). On 9 December, UR representative Cornelius Harris emailed the Detroit Techno (or ' $313^{\prime 6}$ ) mailing list, advising members to boycott the release, providing contact information for Dreyer, Sony Germany, Sony US, and Sony Canada, and inviting members to 'flood Sony's offices worldwide with calls, emails, and faxes' of protest. 'Cover versions traditionally have been done by fans of the original track as an homage to the original', Harris wrote. 'In this case, it is being done as a method of undercutting the sales of the original' ('Underground Resistance').

On 10 December, Dreyer emailed UR to justify the cover version, which he described as 'the talk of the techno community' (quoted in 'Sony Informs' 1999). Stating that a prior request made by Sony to license 'Jaguar' had met with no response, Dreyer wrote

In my way of 'industry thinking' it is a track worth to be available for lot of people, much more than just people going to vinyl shops. [...] As we don't want to be seen as guys who rip off or bootleg a well known track, we have chosen the way of rerecording the track tone by tone. [...] On the $\mathrm{CD}$ will be the original writer and publishing credits that you get the publishing money you deserve. (ibid.)

This quotation's appeal to Detroit 'originality' evinces the aforementioned persistence of aura, and clarifies that the ensuing dispute concerned not uncleared sampling, nor piracy, but an unlicensed replication of UR's record - and, more generally, the appropriation of UR's 'subcultural capital' (as theorised by Thornton 1996, p. 11).

However, Dreyer's correspondence with UR was forwarded to the 313 mailing list - and reprinted at Submerge's website (Harris, 'Sony Response') - thus keeping UR's fans apprised of the developing situation. Mailing list members began responding in droves, to both the list and Sony: many to criticise the 'rip off'; some, on behalf of record stores determined not to carry the cover (SqrRt); and one or two to register scepticism of the conflict's veracity. On 11 December, DJ and producer Terrence Parker weighed in to clarify the legal issues at stake, rejecting Dreyer's claim that Sony could satisfy copyright law merely by printing the appropriate credits on the product:

Sony still has to FIRST get permission in the form of a COMPULSORY LICENCE or SAMPLE CLEARANCE (depending upon the content of this new version which I still have yet to hear) from UR (MIKE \& ROLANDO) before they can LAWFULLY exploit their version of 'JAGUAR'. All of this depends on what Mike and Rolando feel about the content of this 'new version'. ('SONY vs UR')

On 17 December, Dreyer declared that 'Sony Music will not commercially release the track' but hinted 'that a different company will use the idea' (quoted in 'Sony Recalls Fake Jaguar' 1999). In reply, Harris summarised UR's 'feeling' about the 'new version' by recalling Dreyer's own denigration of it, and by objecting to the sleeve art's image 
of a pill, which conjured a drug culture from which Detroit purists had been trying to distance their music since the heyday of hardcore rave in the early 1990s (Sicko 1999, p. 133): 'From the drug references to the lack of musicianship displayed, you have done damage to UR's reputation as a label and a group dedicated to raising the standards of not only techno, but electronic dance music in general' (Underground Fighters 1999). Harris went on to doubt Dreyer's declaration of desistance, and to criticise the rep's attempts to patronise and placate UR (by suggesting that 'at least the UR record will benefit from the story'): 'You claim to understand why UR does not deal with majors, yet you seem to go out of your way to validate our concerns' (ibid.).

Having, in his words, 'received a lot of feedback from the underground' over the previous week (quoted in 'Sony Recalls'), Dreyer emailed a brief apology and a reiteration of Sony's halt on its version on 20 December ('Sony's Deception'). The 313 mailing list continued to buzz with questions, suggestions and speculations, but the case seemed more or less closed - until 10 January 2000, when Harris sent an update: Dreyer had informed him not only that the producers who composed the note-for-note cover version had signed it to BMG, but also that the unauthorised track was ranking among the top ten on German dance charts ('UR vs BMG/Ariola'), and a video was airing on Germany's VIVA music channel (DJ MG 2000, II22).

Harris' subsequent efforts over the course of the month to contact the responsible parties at BMG appear to have been unsuccessful. On 27 January, he was forwarded a brief message from BMG's Clive Rich, who advised him only to contact BMG Ariola Muenchen's lawyer ('Harris Contacted' 2000); three days later, he conversed with BMG's Clemon Williams, 'and he basically had the position of "we don't know what the hell is going on"' (Harris quoted in 'Harris \& BMG's' 2000). A reporter who had first put Harris in touch with Rich observed: 'all systems are go at BMG [...] it seems they have attempted to create a complex chain in order to hide any wrong doing on their part' (quoted in 'Wirestation Reporter' 2000). BMG's complex management structures appeared to afford the company strategic deniability, and the ability to defer UR's demands for resolution ad infinitum.

Nevertheless, by early February, BMG's Inge Schneider had contacted UR with a letter purporting to explain the German company's claim to a legal 'third party licensing agreement' according to German and US royalty collection protocols:

The original publisher of 'Jaguar' Mad Max Music is a member of Harry Fox Agency and therefore subject to aforementioned compulsory licence [sic]. Financially this regulation is no disadvantage for the involved US publishers and authors: The mechanical royalties paid by BMG to GEMA are forwarded to Harry Fox Agency and from there to the original publisher and the authors. (quoted in DJ MG 2000, I[28)

Banks refuted Schneider's claim. According to a message forwarded to the Detroit Techno list on Banks' behalf, UR's track wasn't at that time in Harry Fox's repertoire of properties subject to licensing (Drada 2000). UR also claimed never to have received any royalties that such an agreement would stipulate, and that a chart-climbing cover version would presumably generate (DJ MG 2000, II30).

DJ MG concludes his online account of events with word from Harris 'that BMG is discreetly pulling the copies of their "Jaguar" from the stores'. This account itself represents one of the diverse tactics with which UR carried out its campaign against Sony and BMG. By 4 February 2000, David Bate published a more comprehensive online archive of primary documents in the case (which, somewhat remarkably, remains available at the time of writing). Bate began archiving these materials because he felt that the controversy received insufficient media attention, naming only niche 
magazines like XLR8R, Urb, Muzik and DJ Mag as organs taking an interest in the story (Bate 2000, 'WEB ARTICLES').

Other tactics that UR and its supporters brought to the label's fight with the majors included an online petition, and UR's exhortations to 'flood' Sony and BMG with protest messages; the online archive also includes anecdotal evidence of more direct-action approaches. In March 2000, a debate among Detroit Techno list members arose over what to do when encountering copies of the BMG release in record shops. One list member, upon failing to persuade a shop manager in Las Vegas to take the cover off the shelves, claimed to have hidden them 'at the back of the store', wishing in hindsight that ' $i$ had had tha money with me to buy all of tha records they had', to prevent others from buying it ('more injustices'). This last reflection prompted condemnation for its bottom-line support of the offenders, from a list member who suggested instead that shoppers scratch up copies of the record when finding it in a store (de Yonker). Another member admitted to such vandalism: 'i broke the needle while putting 12" scratches on the last copy at some crappy store in toronto' (Goode).

The dubious veracity of such anecdotes aside, their emergence in cities across North America attests to the effectiveness of UR's publicity in leveraging the 'brand loyalty' of its 'underground' supporters. While the question of whether UR ever initiated legal action against BMG remains unanswered, the label launched yet another tactic. Dreyer seems correct in at least one point that gives us pause to wonder whether the whole débacle wasn't actually hatched as 'anti-marketing marketing' (a ploy that Sicko rejects on UR's behalf [Sicko 1999, p. 147]): the original 'Jaguar' seems to have benefited enormously from the dispute. In a few months in 1999, 'Jaguar' had moved from heavy rotation by Detroit techno's top DJs to ubiquitous rotation among representative DJs in various dance genres around the world. By February 2000, the controversy fuelled the track's appeal for Detroit ambassadors like Derrick May, John Acquaviva, and Jeff Mills, as well as other 'star' DJs, who found in Rocha's track a wordless yet evocative statement of techno's claims on independence and authenticity.

UR moved quickly to capitalise on the track's metonymy as resistance to corporate culture control. On 14 February, Banks circulated an open letter to the 'Global Underground Electronic Music Community'. Banks' message is worth quoting at length, for its 'politics of transfiguration' (Gilroy 1993, p. 37), its sampling of Dreyer's words to conjure the spectre of America's slave economy, its eminently prophetic denunciation of 'false prophets', its Frankensteinian reference to 'the matrix', and its 'anti-marketing' savvy:

UR would like to acknowledge the swarm of digital killer bees that is emerging from the shadows to protect and defend the hive.

Unfortunately at this particular space in time, the beginning of their new millennium, the year 2000, when music the lifeform of sound is looking forward to a future filled with intelligence, tolerance and respect it has to instead look into the now of reality and find itself struggling, surrounded by greed, false prophets, lies, deception and treachery, the old familiar tools of the programmers that have destroyed civilisations, cultures and environments over the centuries. Some of you stand by and watch as they slowly put their fingers around the neck of the music you love! What chance will music have when an 'industry way of thinking' allowed human life to be sold on an auction block. [...]

This is an opportunity for you to analyse the matrix you live in.

As we do battle for the soul of the sound we ask the spirit of the Jaguar and our ancestors to keep giving us the power, strength and guidance to defeat the programmers. 
For those who know, stay low, stay strong, stay ready, stay underground. For those who don't, learn. For those who 'Stole the Soul', live in fear as the spirits will track you into your next lifetimes and beyond. Nothing good will come to you. And for those who don't believe in spirit, then what is it exactly that these note for note covers are lacking?

Consider hostilities at 'Condition Red' the Jaguar will have its revenge!!! (quoted in Marsel 2000)

As with most of Banks' missives, a third party brokered it (establishing the authenticity of Banks' statements seems as difficult as doing so for tapes claiming to issue from Osama bin Laden). This statement exemplifies Banks' refusal of 'the modern, occidental separation of ethics and aesthetics, culture and politics' (Gilroy 1987, pp. 38-9), a refusal that characterises the 'modernist politics' (Gilbert and Pearson 1999, p. 75) of 'underground' ideology (Thornton 1996, p. 145). But what Banks' cryptic prophecy amounts to is a press release hyping UR's Revenge of the Jaguar remix $\mathrm{EP}$, review copies of which had already begun to attract niche media attention.

If BMG was determined to keep its unauthorised knock-off on the market, UR determined to beat this bully on its own turf. With three remixes by some of Detroit's most famous producers (e.g. UR alumnus Mills), as well as two locked grooves, the vinyl release targeted the DJ's DJ. To render UR's releases more affordable in the European market, UR's affiliate label 430 West assumed UK-based distribution of the remixes and re-pressed the original 'Jaguar' (previously available only as an import). 430 West released the remix single on 11 September 2000 ('Resistance' 2000, II4); it soon achieved rotation on BBC Radio One, with a video on MTV UK (Osselaer 2000, I[31). Rocha himself entered the promotional fray with an aggressive tour of European night club duty.

In short, UR flooded the market that Sony and BMG had tried to exploit, with productions that publicised the controversy which had occasioned them, while reasserting the 'authentic' Detroit sound. UR's saturation of the European dance music market with 'Jaguar' CD editions and remixes helped the label to flourish far beyond Detroit, through definitively transnational corporate manoeuvres. The very abundance of online archival documents constitutes a testament to the effectiveness of UR's publicity and releases.

\section{Promotion and presumption}

The economics of 'promotional' dance records further elucidate the issues at stake in UR's tangle with the majors. The vinyl singles available for purchase in DJ specialty shops range from major label releases to 'promotional' or 'white-label' pressings. The latter are often unmarked, with blank labels, or with only scant notation: the name or acronym of a label (e.g. Eric B. and Rakim), an e-mail address (e.g. Wink), the artist's name in ballpoint (e.g. Freeland), etc. Among such cryptic notations, phrases like 'Promo' (e.g. Blame), 'Promotional Record Not For Re-Sale' (e.g. Dillinja et al.), or 'DJ only test press' (e.g. SFB) act both as legal disclaimers and as advertisements that signal a product's rarity or 'bootleg' status. Similar phrases can appear on major-label releases, but carry quite a different tone: 'Promotional copy [. . .] Property of BMG Music Canada. Not for sale or rental. [. . . ] If you paid for this product call [. . .]' (Tamperer).

The discourse of 'DJ promotional use', combined with the relative anonymity, high volume and rapid turnover of dance record production, represents a loophole 
whereby producers can mass-produce a record (although most pressings don't run over a few hundred), ostensibly for promotional expenditure, although record shops regularly make them available for retail sale. This discourse assumes different meanings when offered by an independent producer, on the one hand, and a transnational corporation, on the other. Nevertheless, the tracks issued by these parties - despite their vastly different power relations in the music industry - harbour the mutually promotional effect noted by Dreyer. The increased circulation of 'Jaguar' following its controversy substantiates this effect, which, as Norman Stolzoff writes, is a virtual institution in the copyright-bucking Jamaican dancehall scene: 'being pirated can actually benefit a young artist's career'. Unauthorised reproduction can thus accrue subcultural capital; as Stolzoff's interviewee, dancehall artist Blacka P, puts it, 'You mus' get rob' (Stolzoff 2000, p. 177).

As a label that started literally underground, in the basement of Banks' family home (Oldham 2000, I13), UR mythologises its Detroit roots, while profiting from sales largely external to the city. UR's strident commitment to Detroit and to a core clientele of techno 'purists' seems to disavow the corporate economics that structure its own 'rational organisation of the productive processes' (Gilroy 1987, p. 37) - and its vociferous defence of intellectual property. So what does 'independence' mean in this globalising context? Among the several theories of record label 'independence' surveyed by Keith Negus (1996), David Hesmondhalgh's might typify UR:

Not all small companies are simply small entrepreneurs, argues Hesmondhalgh. Some are attempting to create genuine alternatives. But they are faced with a situation whereby if they want to communicate their music to a wider audience then they have to do this through the capitalist system. (ibid., p. 44)

The material alternative championed by UR is a community-building small-business model, informed by a militant anti-racist philosophy. But as a canonical institution in the dance music niche market, UR also adheres to an 'indie label' ideology, developed by Stephen Lee (1992), and elaborated by Keith Negus as follows:

the notion of 'independence' works as a belief system that defines different working practices and values to that [sic] of the majors, while at the same time providing a way of positioning a small company within an 'alternative' niche market - the latter seemingly contradicting the former. [. . . ] so-called independent companies are not only firmly within the system (rather than outside of it) but [. . .] their 'ideology' of independence deludes them into believing that this is not the case or avoidable. (Negus 1996, p. 45)

While I would hardly characterise UR as 'deluded', I would suggest their success depends as much on their imaginative, Frankensteinian discourse of 'resistance' as it does on their actual products. The case of 'Jaguar' demonstrates on UR's behalf a somewhat contradictory, simultaneous reliance on copyright law as ethical principle and a rejection of the legal establishment. For UR, independence means independence from Adorno and Horkheimer's culture industry, and independence from the institutionalised terrors of racism, but never from capitalism as such. Instead, the label targets specific conditions of late capitalism such as institutional oligarchy, cultural homogenisation, and the corporate restriction of free expression.

Ironically, in the case of UR's copyright skirmish with Sony, Frankenstein appears both as a figure with which Underground Resistance identifies, in its mantra to 'wreak havoc on the programmers', and as one identified by the label in the corporate character of its adversaries. In Banks' above-quoted missive to 'the swarm of digital killer bees', his image of corporate domination over the music industry is not merely an image of murder, but of strangulation: 'some of you stand by and watch as 
they slowly put their fingers around the neck of the music you love!' The privation of both voice and life, strangulation is also the preferred method of Frankenstein's monster: 'I have murdered the innocent as they slept, and grasped to death his throat who never injured me' (Shelley 1992, pp. 213-4). The case also renders ironic the majors' complaints against file-sharing technology, and dramatises 'the endurance of Frankenstein' as a durable trope through which popular cultural producers and consumers imagine, deploy, and trouble technologies of cultural reproduction. But if UR's encounter with the 'presumption' of the major labels reveals some of the conservative, capitalist complicities of music industry independence that are occulted by the ideology of 'underground' independence, this encounter remains an instructive demonstration of how creative and tactical combinations of new and established media can problematise and transform culture against the domination of its production by transnational corporations impelled less by creativity and diversity in expression than by maximising shareholder value.

\section{Endnotes}

1. Bernd Herzogenrath (2000) notes that The Prodigy's name combines meanings of offspring and monstrosity (II7), like those combined in Shelley's 'hideous progeny' (Shelley 1992, p. 10).

2. The Death Star as a figure of nuclear warfare illustrates Kathleen Sullivan's (1999) argument that 'the monsters of the nuclear age [are] typified by Shelley's monster' (quoted in Morton 2002, p. 56).

3. The premise of Glen A. Larson's original series attributed the creation of the Cylons to 'a race of reptiles' (Communists?); in a suggestive rewriting closer to Shelley's text, the 2003 remake of the series attributes responsibility for the $\mathrm{Cy}$ lons directly to human agency.
4. Complementing Corbett's reading of doubled Frankensteinian figures in the realm of production, Reynolds (1999) uses such figures to describe 'the fetishism of science' in dance music's reception: 'Rave became a gigantic psychosocial experiment, with millions of kids modifying their own neurochemistry. [. . .] In rave, kids play the role of both Frankenstein and the monster, experimenting on their own nervous systems' (ibid., pp. 203-4).

5. 'Killer app' is a computing colloquialism, meaning a good or excellent program ('app' being short for 'application'); here Eshun puns on the double entendre of 'killer' as an adjective connoting both 'cool' and 'deadly'.

6. 313 is Detroit's telephone area code.

\section{References}

'430 West'. 2004. Discogs: Building the Definitive Database of Electronic Music < http://www.discogs.com/ label/430_West >

'About Underground Resistance'. [n.d.] Underground Resistance < http:/ /www.undergroundresistance .com/about.html >

Adorno, T. 1991. 'On the fetish character in music and the regression of listening', in The Culture Industry: Selected Essays on Mass Culture, ed. J.M. Bernstein (London, Routledge), pp. 26-52

Aldiss, B. 1986. Trillion Year Spree: The History of Science Fiction (New York, Atheneum)

Askew. 13 January 2000. '430 West joins UR fight against Majors', e-mail to Detroit Techno (313) mailing list

A-Zed. 8 March 2000. 'Re: (313) Jaguar Mixes', e-mail to Detroit Techno (313) mailing list

Baldick, C. 1987. In Frankenstein's Shadow: Myth, Monstrosity, and Nineteenth-Century Writing (Oxford, Clarendon Press)

Bate, D. 4 February 2000. 'WEB ARTICLES REGARDING UR vs SONY???', e-mail to Detroit Techno (313) mailing list

Bettig, R.V. 1992. 'Critical perspectives on the history and philosophy of copyright', Critical Studies in Mass Communication, 9/2, pp. 13-55

Campbell, G. 11 June 2003. Personal interview

Carlyle, T. 1829. 'Signs of the times', Edinburgh Review, rpt. in The Victorian Web: Literature, History E Culture in the Age of Victoria (Singapore) < http:/ / www.victorianweb.org/authors/carlyle/signs1.html>

Clark, D. 15 April 2000. 'Mills / Atkins in the boondocks of Perth', e-mail to Detroit Techno (313) mailing list

Corbett, J. 1994. 'Brothers from another planet: the space madness of Lee "Scratch" Perry, Sun Ra, and George Clinton', in Extended Play: Sounding Off from John Cage to Dr. Funkenstein (Durham, Duke University Press), pp. 7-24 
Davis, E. 2004. 'Roots and wires: polyrhythmic cyberspace and the black electronic', Techgnosis < http:// www.techgnosis.com/cyberconf.html >

Derrida, J. 1981. 'The double session', in Dissemination, trans. B. Johnson (Chicago, University of Chicago Press), pp. 172-286

1992. 'Before the law', in Acts of Literature, ed. D. Attridge, trans. A. Ronell and C. Roulston (New York, Routledge), pp. 181-220

Dery, M. 1993. 'Black to the future: interviews with Samuel R. Delany, Greg Tate, and Tricia Rose', in Flame Wars: The Discourse of Cyberculture, ed. M. Dery (Durham, Duke University Press), pp. 179-222

de Yonker, N.J. 14 March 2000. 'Jaguar: The Detroit Connection', e-mail to Detroit Techno (313) mailing list

DJ MG. February 2000. 'UF Reports: UR vs Sony/BMG - David Vs Goliaths.' The Underground Files $<$ http://www.undergroundfiles.com/ur.html>

Drada, J. 10 February 2000. 'ALERT!!!Re: Jaguar FROM MIKE BANKS', e-mail to Detroit Techno (313) mailing list

Eshun, K. 1998. More Brilliant than the Sun: Adventures in Sonic Fiction (London, Quartet)

Foucault, M. 1981. 'The order of discourse', in Untying the Text, ed. R. Young, trans. I. McLeod (London, Routledge), pp. 48-78

1984. 'What is an author?' in The Foucault Reader, ed. P. Rabinow (New York, Pantheon), pp. 101-20

Frith, S. 2002. 'Illegality and the music industry', The Business of Music, ed. Michael Talbot (Liverpool, Liverpool University Press), pp. 197-216

Gilbert, J., and Pearson, E. 1999. Discographies: Dance Music, Culture and the Politics of Sound (London, Routledge)

Gilroy, P. 1987. 'Ain't No Black in the Union Jack': The Cultural Politics of Race and Nation (Chicago, University of Chicago Press)

1993. The Black Atlantic: Modernity and Double Consciousness (Cambridge, Harvard University Press) 1999. 'Analogues of mourning, mourning the analogue', in Stars Don't Stand Still in the Sky: Music and Myth, ed. K. Kelly and E. McDonnell (New York, New York University Press), pp. 260-71

2000. " "After the Love has Gone": biopolitics and the decay of the black public sphere', in Against Race: Imagining Political Culture Beyond the Color Line (Cambridge, Harvard University Press), pp. 177-206

Goode, S. 14 March 2000. 'RE: Jaguar: The Detroit Connection', e-mail to Detroit Techno (313) mailing list

Grant, P.S., and Wood, C. 2004. Blockbusters and Trade Wars: Popular Culture in a Globalized World (Vancouver, Douglas \& McIntyre)

Harris, C. 9 December 1999. 'Underground Resistance vs Sony, Round 1', e-mail to Detroit Techno (313) mailing list

10 December 1999. 'Sony Response', e-mail to Detroit Techno (313) mailing list

10 January 2000. 'Re: (313) UR vs. BMG/Ariola', e-mail to Detroit Techno (313) mailing list

16 March 2000. 'Re: (313) Jaguar: The Detroit Connection', e-mail to Detroit Techno (313) mailing list

'Harris Contacted by BMG's Clive Rich'. 27 January 2000. Boycott Sony \& BMG: Corporate Multinationals Have Stolen Rolando's Track. Renegade Rhythms Radio < http:/ /www.renegaderhythms.com/articles/ ur/sony_correspondence.html\#121099>

'Harris \& BMG's Clemon Williams Converse'. 30 January 2000. Boycott Sony \& BMG: Corporate Multinationals Have Stolen Rolando's Track. Renegade Rhythms Radio < http:/ / www.renegaderhythms.com/ articles/ur/ur.html\#013000>

Herzogenrath, B. 2000. 'Stop making sense: fuck 'em and their law (. . . it's only 1 and 0 but I like it ... .)', Postmodern Culture, 10/2, < http:/ / muse.jhu.edu/journals/pmc/v010/10·2herzogenrath.html >

Hughes, W. 1994. 'In the empire of the beat', in Microphone Fiends: Youth Music E Youth Culture, ed. A. Ross and T. Rose (New York, Routledge), pp. 147-57

'Indies challenge Sony BMG merger'. 3 November 2004. BBC News (world ed.) < http:/ /news.bbc.co.uk/ 2/hi/entertainment/3979105.stm >

Jones, S. 2002. 'Music that moves: popular music, distribution and network technologies', Cultural Studies, $16 / 2$, pp. 213-32

Jonker, J. 2002. 'Black secret technology (the whitey on the moon dub)', CTheory, 4 December, 51 pars., $<$ http:/ / www.ctheory.net/text_file.asp?pick=358>

'Label Profile: Underground Resistance'. 2002. Burn it Blue: Living and Breathing Dance Music, < http:// www.burnitblue.com/music/Label.asp?Label=31>

Laing, D. 2002. 'Copyright as a component of the music industry', in The Business of Music, ed. M. Talbot (Liverpool, Liverpool University Press), pp. 171-94

Latham, R. 2002. Consuming Youth: Vampires, Cyborgs, and the Culture of Consumption (Chicago, University of Chicago Press)

Lee, S. 1992. 'Re-examining the concept of the independent record company: the case of Wax Trax! Records', Popular Music, 14/1, pp. 13-32

Levine, G., and Knoepflmacher, U.C. (eds.) 1979. The Endurance of Frankenstein: Essays on Mary Shelley's Novel (Berkeley, University of California Press)

Marsel. 14 February 2000. 'Fwd: A word from Mad Mike for the press', e-mail to Detroit Techno (313) mailing list 
Marshall, L. 2002. 'Metallica and morality: the rhetorical battleground of the Napster wars', Entertainment Law, 1/1, pp. 1-18

McCall, T. 2001. This is Not a Rave: In the Shadow of a Subculture (Toronto, Insomniac Press)

McClary, S. 1991. Feminine Endings: Music, Gender and Sexuality (Minneapolis, University of Minnesota Press)

1994. 'Same as it ever was: youth culture and music', in Microphone Fiends: Youth Music E Youth Culture, ed. A. Ross and T. Rose (New York, Routledge), pp. 29-40

McLeod, K. 2003. 'Space oddities: aliens, futurism and meaning in popular music', Popular Music, 22/3, pp. 337-55

'more injustices with Sony's rip off of Jaguar'. 21 February 2000. E-mail to Detroit Techno (313) mailing list

Morton, T. 2002. A Routledge Literary Sourcebook on Mary Shelley's Frankenstein (London, Routledge)

Negus, K. 1996. Popular Music in Theory (Middletown, Wesleyan University Press)

Nye, D. 1994. American Technological Sublime (Cambridge, MIT Press)

Oldham, A. 14 February 2000. 'Feb / Mar Mixer reviews (in advance)', e-mail to Detroit Techno (313) mailing list

Osselaer, J. September 2000. 'Lawrence Burden interview', Overload < http://www.overloadmedia.co. uk/archives/interviews/lawrence_burden.php >

Oxford English Dictionary, 2nd edn. 1989.

Parker, T. 11 December 1999. 'SONY vs UR (TP's 2 cents)', e-mail to Detroit Techno (313) mailing list

Porcello, T. 1991. 'The ethics of digital audio-sampling: engineers' discourse', Popular Music, 10/1, pp. 69-84

PW. 10 December 1999. 'RE: UR vs. SONY', e-mail to Detroit Techno (313) mailing list

‘Resistance against ". . . Jaguar" is useless'. 18 August 2000. New Music Express < http:/ / www.nme.com/ news/4743.htm >

Reynolds, S. 1998. Generation Ecstasy: Into the World of Techno and Rave Culture (New York, Little, Brown \& Co.)

1999. 'Ecstasy is a science: techno-romanticism', in Stars Don't Stand Still in the Sky: Music and Myth, ed. K. Kelly and E. McDonnell (New York, New York University Press), pp. 199-205

2000. 'Kosmik dance: Krautrock and its legacy', in Modulations: A History of Electronic Music: Throbbing Words on Sound, ed. P. Shapiro (New York, Caipirinha), pp. 24-37

Rose, T. 1995. 'Soul sonic forces: technology, orality, and black cultural practice in rap music', in Sounding Off! Music as Subversion / Resistance / Revolution, ed. R. Sakolsky and F. Wei-han Ho (Brooklyn, Autonomedia), pp. 97-107

Saunders, D. 22 January 2005. 'Who's afraid of the 400-channel universe?', Globe \& Mail (Toronto), p. F3

Schumacher, T.G. 1995. "“This is a sampling sport": digital sampling, rap music and the law in cultural production', Media, Culture E Society, 17, pp. 253-73

Seltzer, M. 1993. 'Serial killers (1)', differences, 5/1, pp. 92-128

Shapiro, P. (ed.) 2000. Modulations: A History of Electronic Music: Throbbing Words on Sound (New York, Caipirinha)

Shelley, M. 1992. Frankenstein; or, The Modern Prometheus (1831), ed. M. Hindle (London, Penguin Classics) Sicko, D. 1999. Techno Rebels: The Renegades of Electronic Funk (New York, Billboard Books)

Slobin, M. 1993. Subcultural Sounds: Micromusics of the West (Hanover, Wesleyan University Press)

Smith, R. 27 July 2002. 'Step outside the church of business for a moment', Globe and Mail (Toronto), p. R11 Solokowski, J. 2 November 2000. 'Re: [313] Ken Ishii', e-mail to Detroit Techno (313) mailing list

'Sony Informs UR of Their Intentions'. 10 December 1999. Boycott Sony \& BMG: Corporate Multinationals Have Stolen Rolando's Track. Renegade Rhythms Radio < http:/ /www.renegaderhythms.com/articles / ur/sony_correspondence.html\#121099>

'Sony Recalls Fake Jaguar'. December 1999. Boycott Sony \& BMG: Corporate Multinationals Have Stolen Rolando's Track. Renegade Rhythms Radio <http://www.renegaderhythms.com/articles/ur/ sony_correspondence.html\#121799>

'Sony's Deception'. 20 December 1999. Boycott Sony \& BMG: Corporate Multinationals Have Stolen Rolando's Track. Renegade Rhythms Radio <http://www.renegaderhythms.com/articles/ur/ sony_correspondence.html\#122099>

SqrRt. 10 December 1999. 'RE: (313) Underground Resistance vs Sony, Round 1', e-mail to Detroit Techno (313) mailing list

Stokes, M. 2000. 'East, West, and Arabesk', in Western Music and Its Others: Difference, Representation, and Appropriation in Music, ed. D. Hesmondhalgh and G. Born (Berkeley, University of California Press), pp. 213-33

Stolzoff, N. 2000. Wake the Town and Tell the People: Dancehall Culture in Jamaica (Durham, Duke University Press)

Thornton, S. 1996. Club Cultures: Music, Media and Subcultural Capital (Hanover, Wesleyan University Press) Underground Fighters. 16 December 1999. ‘UR vs Sony round 2', e-mail to Detroit Techno (313) mailing list Watkins, T. 22 October 2000. 'Re: [313] is rolando too good for ben sims because of D records?' e-mail to Detroit Techno (313) mailing list 
Williams, B. 2001. 'Black secret technology: Detroit techno and the information age', in Technicolor: Race, Technology, and Everyday Life, ed. A. Nelson and T.L.N. Tu (New York, New York University Press), pp. $154-76$

Williams, R. 1958. Culture and Society 1780-1950 (London, Penguin Books)

'Wirestation Reporter Discovers BMG Coverup'. 27 January 2000. Boycott Sony E BMG: Corporate Multinationals Have Stolen Rolando's Track. Renegade Rhythms Radio < http:/ / www.renegaderhythms.com/ articles/ur/simon.html>

Wraight, J., and Nodu, T. 1996. 'Underground resistance: designs for sonic revolution', Ele-King Magazine 7, rptd in Straight No Chaser, 2/5 (1999), pp. 20-9

\section{Discography}

Acen, 'Cylon'. F-111. 1999

Andora, 'Blade Runner (Digital Blonde's Blonderunner mix)'. Infusion. 1999

Art of Noise with Max Headroom, 'Paranoimia'. Chrysalis. 1986

Aztec Mystic, 'Jaguar', Knights of the Jaguar EP. Underground Resistance. 1999

Eric B. and Rakim, 'I know you got soul (remix)'. Arc. [n.d.]

'Mad' Mike Banks, Death Star EP. Underground Resistance. 1992

Blame, Upstart Vol. 1. Moving Shadow. [n.d.]

Capital J, Untitled Star Wars remix. White label. [n.d.]

Jon Carter, 7 Live \#1. Seven. 2002

Dillinja and Lemon D, 'Fluid / Hard Noize'. Test. 1998

Dylan and B-Key, 'Dark Skies (remix)' / 'The Onslaught'. Cylon. 2001

Adam Freeland, 'Smells Like Teen Spirit (remix)'. White label. [n.d.]

Kenny 'Dope' Gonzalez, 'Battlestar Galactica', Kenny's House EP. Dope Wax. [n.d.]

Love Child, 'Time Travellers', in Dogwhistle: The Life and Times of an After Hours D.J. Quality. 1995

Giorgio Moroder, Music from 'Battlestar Galactica' and Other Compositions. Casablanca. 1978

Parliament, Clones of Dr. Funkenstein. Casablanca. 1976

The Prodigy, 'Out of Space (original mix)'. XL. 1992

Madam Zu and Jon Doe, '999 Matrix (The Red Pill)'. Mohawk. [n.d.]

Max Romeo and the Upsetters, 'Chase the Devil', War ina Babylon. Mango. 1976

Messiah, 21st Century Jesus. American. 1994

Rufige Cru, 'Terminator II', Have a Nice Trip. Quality. 1993

SFB feat. R.E.M., 'Abusing My Religion'. White label. [n.d.]

Sir Round, 'The Imperial March.' Techno Club. 1999

The Tamperer feat. Maya, 'If you buy this record your life will be better'. BMG. 1998

The Timelords, 'Doctorin' the Tardis'. KLF Communications. 1988

Pete Tong, Essential Mix 2000. Essen. 2000

Ultramagnetic MCs, 'Critical Beatdown', Critical Beatdown. Next Plateau. 1988

Various artists, MTV Extreme. White Island. 2001

Various artists, Techno! The New Dance Sound of Detroit. Virgin. 1988

Josh Wink, 'Higher State of Consciousness (Wink1 remix)'. White label. [n.d.]

\section{Filmography}

Battlestar Galactica: Saga of a Star World. 1978. ABC/Universal

Battlestar Galactica. 2003. Sky TV/USA Cable

Blade Runner (Ridley Scott). 1982. Warner Bros./Ladd

The Matrix (Andy Wachowski and Larry Wachowski). 1999. Warner Bros.

Max Headroom. 1987. Warner Bros./Lorimar

Robocop (Paul Verhoeven). 1987. Orion

Star Trek: The Next Generation. 1987. Paramount

Star Wars (George Lucas). 1977. 20th Century Fox

The Terminator (James Cameron). 1984. Orion

Videodrome (David Cronenberg). 1983. Universal 